\title{
Some aspects of modern Altai horse breeding
}

\author{
DOI: 10.31551/2410-2725-2019-5-3-351-372
}

\section{Ignatyeva Olga Petrovna}

Russian museum of ethnography, researcher, curator of the illustrative fund. Russia. St.Petersburg. E-mail: kopeishik@yandex.ru

\begin{abstract}
XX century brought collosal adjustments to the lifestyle of the Altaians (the term Altaians here is used collectively and unites Altai-kiji, Telengits, Kumandins, Chelkans and Tubalars). The nomadic groups completely transited to settled life, the system of property relations was changed several times, the inhabitants of the region were involved in government programs for the development of agriculture, and mandatory standardized education was introduced. The beginning of the 21 st century introduced new communication opportunities, new materials and new directions for the development of the economy, while at the same time the level of employment, medical and veterinary services decreased. The Altai breeders turned out to be left to themselves and focused on those types of economic activity that they consider the most economically viable and fit into the framework of traditional cultural ideas about legitimate ways of managing.

The result was a partial return to traditional farming methods, and an assessment of the property level of the family, taking into account the livestock of farm animals, in particular horses. Continuous development and a peculiar renaissance of the horse-breeding tradition, with the almost complete economic inexpediency of horse-breeding as such, require an indispensable fixation and study of researchers. This article provides a brief overview of the material aspects of modern Altai horse breeding. Methods for keeping and breeding horses are considered, data on the types and existence of horse equipment are presented, and modern samples are compared with material objects known from museum collections. Also provides brief information on common types of equestrian sports.
\end{abstract}

Keywords: Altai; modern material culture; horse breeding; horse equipment; mobility; national sport; masculine world; national identity.

\section{Қазіргі кезеңдегі алтайлық жылқы шаруашылығының кейбір аспектілері}

\section{Игнатьева Ольга Петровна}

Ресей этнографиялық мұражайы, ғылыми қызметкер, иллюстративті қорды сақтаушы. Ресей Федерациясы. Россия. Санкт-Петербург қ., E-mail: kopeishik@yandex.ru

Аңдатпа: XX ғасыр алтайлықтардың өмір салтына көптеген өзгерістер әкелді ("алтайлықтар" термині алтай-кижи, теленгит, кумандықтар, челкандар, тубаларды біріктіретін жинақтаушы мағынада қолданылады). Көшпелі топтар толығымен отырықшылыққа ауысты, бірнеше рет мүлік қатынастар жүйесі өзгерді, аймақ тұрғындары ауылшаруашылықты дамытудың мемлекеттік бағдарламасына тартылып, міндетті стандартталған білім беру енгізілді. XXI ғасырдың басында шаруашылықтың жаңа коммуникативті мүмкіндіктері, жаңа материалдар мен жаңа бағыттар енгізілді, бірақ соның өзінде жұмыспен қамтамасыз ету, тұрғындарға медициналық және ветеринарлық қызмет етудің деңгейі төмендеді. Алтайдың мал өсірушілері шаруашылықты заңды тәсілдері туралы дәстүрлі мәдени көріністер шеңберінде қалыптасқан және экономикалық тиімді деп есептеген шаруашылық түрлерінде өздерімен өздері әрекет етті. Бұлардың нәтижесі ауылшаруашылық жүргізудің дәстүрлі тәсілдеріне біртіндеп қайта оралу, ауылшаруашылық мал басы, атап айтқанда, жылқы басы есебімен отбасының мүліктік деңгейін бағалау шаралары болды. Жылқы шаруашылығының толық экономикалық орынсыздығы кезінде жылқы шаруашылығы дәстүрінің үздіксіз дамуы мен өзіндік қайта жаңғырту зерттеушілерден міндетті бекітуді және зерттеуді талап етеді. Бұл мақалада алтайлықтардың қазіргі жылқы шаруашылығының материалды аспектісіне шолу жасалған. Жылқы ұстау және өсіру тәсілдері қарастырылып, ат абзелдерінің түрлері туралы мәліметтер келтіріледі. Сонымен қатар, мұражай топтамаларындағы материалды нысандарды қазіргі үлгілермен салыстырған. Ат жарыстарының кең тараған түрлері туралы қысқаша мәліметтер берілген.

Түйін сөздер: Алтай; қазіргі материалды мәдениет; жылқы шаруашылығы; ат әбзелдері; ұтқырлық; ұлттық спорт; ерлер әлемі; этникалық бірегейлік. 


\title{
Некоторые аспекты современного алтайского коневодства
}

\section{Игнатьева Ольга Петровна}

Российский этнографический музей, научный сотрудник, хранитель иллюстративного фонда. Россия. Санкт-Петербург. E-mail: kopeishik@yandex.ru

\begin{abstract}
Аннотация: XX в. внёс огромные коррективы в образ жизни алтайцев (термин «алтайцы» используется в собирательном значении, объединяющем алтай-кижи, теленгитов, кумандинцев, челканцев и тубаларов). Произошел полный переход кочевых групп на оседлость, несколько раз изменялась система имущественных отношений, жители региона оказались вовлечены в государственные программы развития сельского хозяйства, было внедрено обязательное стандартизированное образование. Начало XXI в. привнесло новые коммуникационные возможности, новые материалы и новые направления развития хозяйства, в то же время снизился уровень трудоустройства, медицинского и ветеринарного обслуживания населения. Животноводы Алтая оказались предоставлены сами себе и сосредоточились на тех видах хозяйственной деятельности, которые считали наиболее экономически целесообразными и укладывающимися в рамки традиционных культурных представлений о легитимных способах хозяйствования. Результатом стал частичный возврат к традиционным методам ведения сельского хозяйства, и оценки имущественного уровня семьи с учётом поголовья сельскохозяйственных животных, в частности лошадей. Непрерывное развитие и своеобразный ренессанс коневодческой традиции при почти полной экономической нецелесообразности коневодства как такового требуют от исследователей непременной фиксации и изучения. В данной статье дан краткий обзор материальных аспектов современного коневодства алтайцев. Рассматриваются способы содержания и разведения лошадей, приводятся данные о типах и бытовании конской амуниции, проводится сравнение современных образцов с материальными объектами, известными по музейным собраниям. Также приводятся краткие сведения о распространенных видах конного спорта.

Ключевые слова: Алтай; современная материальная культура; коневодство; конское снаряжение; мобильность; национальный спорт; мужской мир; этническая идентичность.
\end{abstract}

\section{UDC/УДКЗ9.636.1}

\section{Некоторые аспекты современного алтайского коневодства}

\section{О.П. Игнатьева}

Введение. В настоящей статье рассматриваются повседневные аспекты алтайского коневодства: перемены, происходящие в кочевнической культуре под влиянием внешних факторов, и их воздействие на коневодческую традицию. Начало русского освоения Южной Сибири запустило активный и непрерывный процесс изменения традиционной культуры, приведший к существенным трансформациям быта и воззрений. Уже в XIX в. исследователи отмечали сокращение поголовья скота и лошадей, уменьшение ареала кочевий. XX в. стал веком перехода к полной оседлости. Какое место занимают кони в жизни не кочующих кочевников, как видоизменилась традиция - вот те вопросы, на которые хотелось бы ответить. Данная статья призвана, хотя бы отчасти, в общих чертах, восполнить существующую информационную лакуну, объединить основные имеющиеся сведения по алтайскому коневодству, и ввести в научный оборот некоторые новые данные по материальной культуре.

Традиционно исследователи выделяют две группы алтайцев: северную и южную. К северной группе относят: кумандинцев, тубаларов, челканцев (лебединцев) - полуоседлых охотников-скотоводов. В состав южной группы включают алтай-кижи и теленгитов - скотоводов-кочевников центрального Алтая. Провозглашение кумандинцев, теленгитов, тубаларов и челканцев отдельными коренными малочисленными народами, является важным 
историческим, социальным и политическим событием, однако, не препятствует применению устоявшихся в науке собирательных терминов «алтайцы северные» и «алтайцы южные», либо просто «алтайцы» в том случае, когда речь не идёт о конкретном народе либо этнической группе. Из-за специфики имеющихся материалов статья преимущественно построена на данных по коневодству у алтайцев южной группы.

Материалы и методы. При работе над темой применялись базовые методы полевой этнографрии, такие как включённое и не включённое наблюдение, интервьюирование, а также элементы сравнительноисторического анализа, исследование вещевых музейных памятников и объектов материальной культуры, находящихся в частном владении, а также архивных текстовых и визуальных материалов. В основу легли полевые материалы автора за 2006, 2008, 2012 годы, материалы архивов и фондов Российского этнографического музея и Музея антропологии и этнографии имени Петра Великого (Кунсткамера) РАН, а также материалы личной переписки автора с носителями культуры. Особую благодарность автор выражает Белековой Э.А., Кукпеевой Ю.Е., Тадиной Н.А., Тадышевой Н.О., а также жителям Республики Алтай, любезно согласившимся поделиться своими знаниями.

Обсуждение. Алтайское коневодство в литературе освещено скудно, большинство ранних исследователей Алтая, говоря о лошадях, упоминали их вскользь, в связи с личным опытом использования в поездках, как животных некрасивых, но весьма хорошо приспособленных к условиям гор. В.В. Радлов был первым, уделившим внимание алтайскому коневодству и оценившим эстетические достоинства лошадей алтайского разведения. Возможно, свою роль сыграл тот факт, что в 1870 г. с ним по Алтаю путешествовал ветеринар Калнинг, составивший морфологическое описание (Радлов, 1989: 145). Различные аспекты культуры, так или иначе связанные с конём, освещали в своих трудах Анохин А. В., Вайнштейн С. И., Вербицкий В.И., Дьяконова В.П., Дыренкова Н.П., Потапов Л.П., Каралькин П.И., Каруновская Л.Э., Радлов В.В., Тадина Н.А., Тощакова Е.М., Шатинова Н.И., Швецов С.П. и другие авторы, писавшие об алтайцах. Так как конь является, своего рода, универсалией алтайской традиции, писать об алтайской этнографии не упоминая лошадей практически невозможно. Отдельно хотелось бы отметить работы Тюхтеневой С.П.: автор впервые за долгое время целенаправленно обращается к вопросам скотоводства, вводя в научный оборот новые данные полевых исследований.

Результаты. На рубеже XIX и XX вв. иппологи официально выделили алтайских лошадей в отдельную аборигенную породу, имеющую устойчивые соматические показатели, такие как рост в холке, длина спины и т.п.

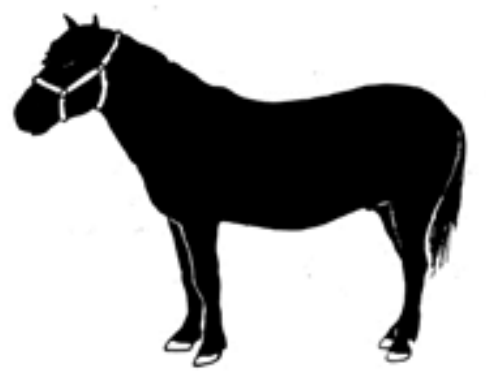

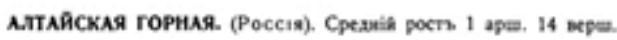

Рисунок 1. Лошадь алтайской породы по книге В.Г. Бороздина 
В книге Бороздина В.Г. «Альбом разных русских и иностранных пород лошадей», вышедшей в Санкт-Петербурге в начале XX в., (Бороздин:174-175) опубликовано первое изображение алтайской лошади.

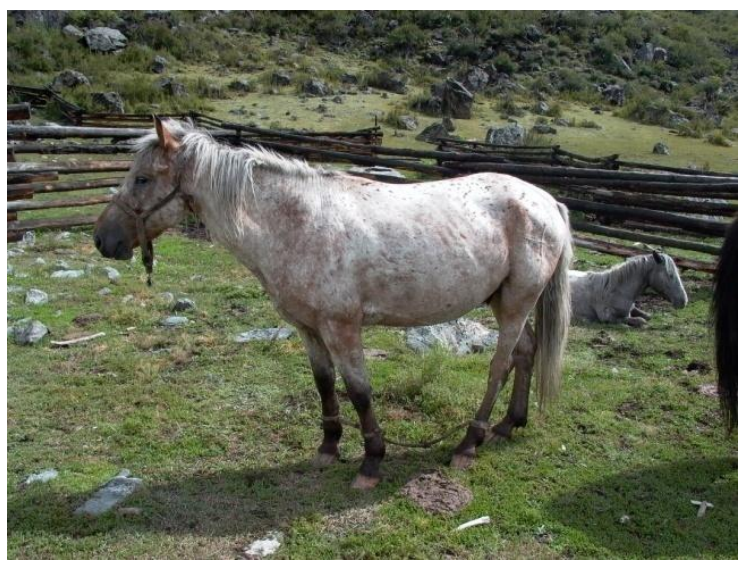

Рисунок 2. Лошадь алтайской породы. Улаганский р-н Р. А., Полевые материалы автора (далее ПМА), 2006 г.

В конце 1940-х гг. алтайскую породу лошадей назвали ойротской (Жилинский, 1948: 54-64). Под таким названием порода была известна до января 1948 г., после чего снова стала называться алтайской (Лобанова, Трушников, 2017: 83). На протяжении XX в. предпринимались многочисленные попытки изменить морфологические показатели алтайской аборигенной породы. Селекция велась по двум основным направлениям:

1. Увеличение роста животных, с целью их адаптации для нужд армии и сельского хозяйства.

2. Увеличение мясомолочной продуктивности при сохранении способности к круглогодичному содержанию на подножном корму.

Одним из инициаторов первого направления селекционной работы стал выдающийся представитель алтайского народа Аргымай Кульджин - богатый скотовладелец и конезаводчик из рода майман, который активно скрещивал местных маток с более рослыми жеребцами кузнецкой и даже арабской пород (Лобанова, Трушников 2017: 84). Согласно биографии Кульджина, излагаемой как нарратив, в 1910-1911 гг. он привёз из Англии племенных английских лошадей, активно использовал их в селекции, и в 1930-х гг., возглавил Ябоганский конезавод ${ }^{1}$. На текущий момент автор не обладает документальными данными, способными подтвердить эти сведения. Фактом является использование лошадей кульджиновской селекции в советской племенной работе в первой половине XX в. (Лобанова, Трушников, 2017: 84). Во время Великой Отечественной войны алтайские колхозы поставляли для нужд Красной армии животных вполне пригодных для ремонта. В послевоенное время значимость кавалерии существенно уменьшилась, что привело к упадку верхового коневодства практически на всей территории СССР и снижению интереса к аборигенным породам, как к потенциальному транспортному и тягловому сельскохозяйственному ресурсу. На первый план вышла

\footnotetext{
1 Полевые фотоматериалы автора (далее ПМА) 2006: Архив Российского этнографического музея (далееАРЭМ) Ф.10 Оп.1 Д. 204 Л.9-9 об.
} 
продуктивная селекция. В 1978 г. начались работы по скрещиванию местных лошадей с лошадьми литовской, русской и советской тяжеловозных пород. К 2000 г. работа над новоалтайской породой велась в шести хозяйствах Республики Алтай. В Усть-Коксинском районе: ТОО Агросоюз «Амурский», ТОО «Холзун», в Усть-Канском районе конезавод АХ «Кырлык», в Шебалинском районе конезавод ТОО «Беш-Озек», АО «Новый путь» и в ОПХ «Теньгинское» Онгудайского районе. Также в работе принимали участие хозяйства Алтайского края. Курирует селекционную работу ВНИИ Коневодства (Никонова, 2000: 11-55).

Улаганский район стал местом сохранения чистокровной популяции алтайских лошадей (Чаптынов 1986: 15), чему во многом способствует относительная изолированность его территории от других мест республики. В современных частных хозяйствах селекционная работа снова ориентируется на улучшение верховых, скоростных и спортивных качеств коней (Игнатьева, 2012: 131)

Устойчивость морфологических признаков и высокую приспособленность алтайской лошади к экологическим условиям региона невозможно объяснить только естественным отбором, налицо результат многовековой селекционной работы. Эпические предания сохраняют для нас образ богатырского коня, не имеющего изъянов, воплощающий представления об идеальных эстетических и рабочих качествах животного:

Очи-Дьерен, [конь] из клыкастых,

Тут же шумно встряхнулся,

[Воздух] сотрясая, звонко заржал,

Передними ногами перебирает,

Задними ногами приплясывает.

Хвост в девяносто две пряди

О щетки бьется,

Челка в семьдесят косичек

Два глаза его прикрывает.//

Два одинаковых уха-ножницы его

На небе бело-синие [облака]

Туда-сюда разгоняли,

Два одинаковых черных глаза его,

Будто луна при затмении, поворачивались <..>

Мой кроваво-рыжий [конь], подобный радуге... (Алтайские героические сказания, 1997: 97).

В поэтической форме описано энергичное здоровое животное с хорошо сформированным шерстным покровом, не имеющее физических изъянов. В литературе принято интерпретировать эпитет «конь из клыкастых» как подчёркивающий незаурядные качества и темперамент животного (Алтайские героические сказания, 1997: 593). Полагаем, что существует более прозаическое объяснение: у жеребцов и меринов, достигших возраста 5 лет, т.е. полностью сформировавшихся, появляются клыки. Подчёркнутую парность глаз и ушей животного можно понимать как отсутствие фризических недостатков, однако следует помнить, что идея парности и симметричности имеет важное значение для алтайской культуры. Парностью подчёркивается принадлежность существа к человеческому, среднему миру, нормальность, дружественность.

Бонитировка лошадей в алтайской традиции осуществлялась знатоками из числа мужчин-коневодов. Среди признаков хорошего животного информанты 
алтай-кижи упоминают прямые ноги, прямую спину, широкие грудь и круп, высоко поставленную голову². Выбраковка «лишних» жеребцов из племенного разведения осуществлялась путем холощения. Для алтайцев был характерен кровавый способ кастрации. В качестве вспомогательного приспособления могли использовать деревянные тиски, состоящие из двух обработанных дощечек, соединенных кожаным ремешком. Информанты-теленгиты из Улаганского района упоминали щипцы из древесины берёзы ${ }^{3}$. В описи предметов, привезённых А.Н. Глуховым в 1925 г. в Этнографический Отдел Русского Музея (Российский этнографический музей) из экспедиции к тубаларам значится «набор коновала для холощения жеребцов» «ајгыркӓстӓн-кызыур» включающий в себя щипцы деревянные с насечками для зажимания мошонки в момент ее вылущивания ножом; «дісһыч» - пестик деревянный, которым расширяют края разреза мошонки после вылущивания, и «кааргыч» - полосу железа, которой прижигают растертые края разреза для полной остановки кровотечения ${ }^{4}$. От алтай-кижи бассейна р. Катуни кастрационные деревянные щипцы поступили в РЭМ под названием «сапсалы» ${ }^{5}$.Прямые с одной стороны, части щипцов могли иметь с другой стороны выемку для мошонки. Наличие подобного зажима существенно упрощало операцию. Кастрируют жеребцов сами, так как ветеринаров нет. Проведение операции в трехлетнем возрасте информанты объясняют поздним наступлением у местных лошадей половой зрелости ${ }^{6}$. В современном теленгитском хозяйстве процесс кастрации осуществляется следующим образом: жеребца валят на землю, завязывают петлю из аркана у него на шее и продевают в нее задние ноги коня, притягивая их таким образом, чтобы лишить животное возможности сопротивляться и открыть доступ к мошонке. Далее накладывают специальные ветеринарные тиски, делают надрез и по одному удаляют семенники. Края раны обрабатывают антисептическим препаратом. Для проведения операции нужны силы 3-4 человек. Процедуру проводят весной, для того, чтобы животное легче оправилось от после операционного недомогания ${ }^{7}$. По всей видимости, процедура кастрации мало изменилась и в традиции была аналогична зафиксированной Вайнштейном С.И. на тувинском материале, отличается только возраст животных, так как тувинцы холостили годовалых жеребцов (Вайнштейн, 1972: 33-34). Сведения, касающиеся кастрации, приводимые Радловым В.В., представляются несколько упрощёнными (Радлов, 1989: 148). Кастрированное животное обладает обычно более покладистым нравом и, следовательно, лучшими верховыми качествами. Для обозначения самого процесса бытуют различные термины, в зависимости от местности. Так, в Улаганском районе используют словосочетание «кезиптурган», букв. переводе «резать», в Онгудайском районе употребляют выражение «арчыптурган», т.е. «чистить» (Из личной переписки автора с Белековой Э.А., теленгит, сӧӧксагал).

Жеребцов, оставленных на племя, соединяют с косяком, состоящим из нескольких кобыл, жеребят, не достигших полового созревания, и меринов. Количество особей в такой группе колеблется от 20 до 60, число кобыл при одном косячном от 8 до 20 (Радлов, 1989: 146). Производитель остается в

\footnotetext{
${ }^{2}$ АРЭМ Ф. 10 Оп.1 Д.204 Л.9.

${ }^{3}$ АРЭМ Ф.10 Оп.1 Д.204 л.33 об.

${ }^{4}$ АРЭМ, свод коллекционных описей, кн.4043-4333: ЛЛ. 569-570; тубаларские термины приведены в транслитерации Глухова.

${ }^{5}$ АРЭМ, книга коллекционных описей №164, Л.20.

${ }^{6}$ АРЭМ Ф.10 Оп.1 Д.204 Л.16.
}

${ }^{7}$ АРЭМ Ф.10 Оп.1 Д.204 Л.33 об. 
табуне до возраста 16-18 лет, после чего заменяется молодым животным. Старого жеребца продолжают использовать в работе ${ }^{8}$. Подсчёт лошадей в алтайской культуре вёлся весьма приблизительный, так как исчислялось количество жеребцов-производителей, и, исходя из этого, определялось поголовье. Среди алтайцев бытует устойчивое поверье, согласно которому на прямой вопрос о количестве скота в хозяйстве следует отвечать иносказательно, чтобы стада не оскудели. В качестве стандартного ответа фригурирует фраза «две-три головы» или «один табун/стадо» (Тюхтенева, 2017: 131). Таким образом, точное количество коней известно только владельцу и его ближайшему окружению. Не в каждом алтайском хозяйстве содержат количество лошадей, достаточное для стабунивания. Зачастую ограничиваются несколькими верховыми животными, содержащимися при доме, или пасущимися в табунах родственников. В ситуации, когда в хозяйстве нет жеребца, и для случки используется чужой производитель, владельцы кобыл, следуя сложившейся традиции, «благодарят» владельца жеребца «за приплод» деньгами или подарками (Из личной переписки автора с д.и.н. Тадиной Н.А. алтай-кижи, сӧӧктодош). Подобная практика описана на тувинском материале, где в качестве вознаграждения владелец жеребца получал барана (Даржа, 2003: 16). Используя чужого производителя, хозяева коней вынуждены отказываться от табунного метода разведения и искать другие способы случки. В 2006 г в Улаганском районе мне удалось наблюдать небольшой косяк лошадей, состоявший из производителя, четырех кобыл и жеребенка. Животные располагались на территории стоянки в черте ограды. Жеребец и кобыла, находящаяся в состоянии гона, были за повод недоуздка привязаны к колышку, вбитому в землю. Остальные особи в табуне паслись спутанными. Такое подобие варковой случки применимо для малых хозяйств и обеспечивает достаточно высокую вероятность покрытия кобылы. Использование искусственного осеменения не нашло широкого применения в алтайском коневодстве.

Выжеребка табунных кобыл приходится на апрель-май. В прошлом кобылиц приучали к дойке подсосным методом. Животные достаточно быстро привыкали к процедуре и самостоятельно подходили к своему месту у привязи. Фиксировали лошадей поводом недоуздка. Доили, по словам информантов, до 5-6 раз в день. Кобыл и жеребят привязывали к специально натянутым веревкам «јеле», дойку осуществляли в загонах «чеден» (букв. - изгородь). В течение дня жеребята находились у привязи, а ночью их отпускали к матерям. Дойных кобыл прикармливали сеном, которое заготавливали специально для этой цели вручную и сушили свернутым в жгуты на кустах и деревьях. Во время доения кобылам могли спутывать переднюю и заднюю ноги ${ }^{9}$, или подвязать переднюю левую ногу на весу, в согнутом положении ${ }^{10}$. По данным, относящимся к первой половине XX в., доили кобыл и женщины, и мужчины, хотя чаще всего на фотография начала $\mathrm{XX}$ в. лошадь доят замужние женщины. Доящий обхватывал левую заднюю ногу животного стоя на одном колене ${ }^{11}$. Жеребенка подпускали к вымени на специальном поводке, затем, через несколько минут, оттаскивали и начинали дойку, после чего детёныша снова отпускали, и он досасывал остатки молока. Подводить жеребенка и

\footnotetext{
${ }^{8}$ АРЭМ Ф.10 Оп.1 Д.204 Л.17об.

${ }^{9}$ АРЭМ Ф.10 ОП.1 Д.204 Л.20-21.

${ }^{10}$ Музей археологии и этнографии (далее МАЭ) 4124-51.

11 МАЭ 4124-35 Данилин А.Г., Каруновская Л.Э. Доение кобылы. Фотоотпечаток. Алтайцы. Алтай, Шебалинский р-он (Ойротская автономная область, Шебалинский аймак), 1929.
} 
оттаскивать его входило в обязанности детей - подростков, как мальчиков, так и девочек. В настоящее время доение кобыл массово не практикуется, и кобылье молоко в повседневную пищу не употребляется.

Таврение жеребят происходит на втором году жизни, преимущественно в крупных хозяйствах. Метка выжигается на левом стегне лошади и может представлять собой как буквы и цифры, так и родовой знак собственности «танма».

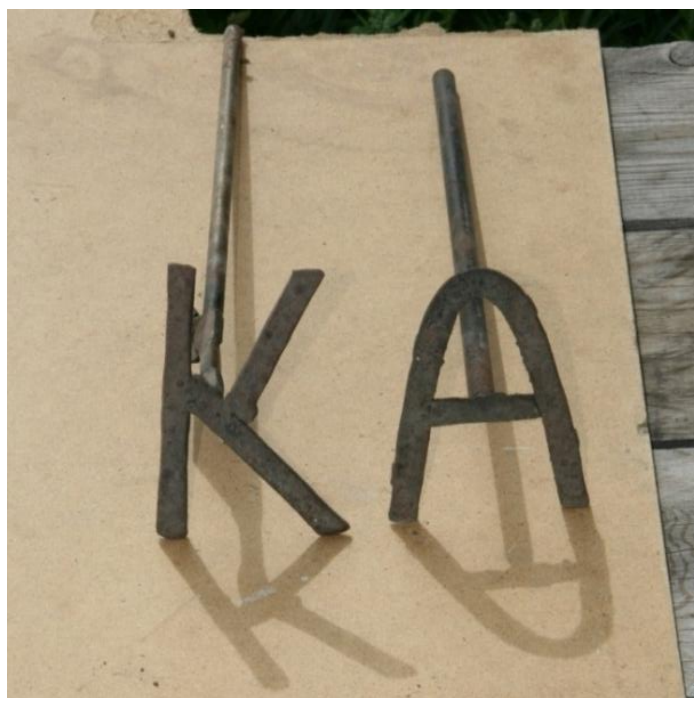

Рисунок 3. Буквенные клейма. Шебалинский район Республики Алтай. ПМА, 2012 г.

Распределены такие тамги по фамилиям, и видоизменяются от изначальной родовой формы путём добавления дополнительных линий или значков. Сбору и интерпретации информации о родовых тамгах алтайцев посвящена монография Ямаевой Е.Е. (Ямаева, 2004), снабженная подробными графическими таблицами. Согласно данной монографии наиболее часто встречающимися тамгами являются корыто «тоскуур», месяц «ай», лук / самострел «айя», удила «суулук», бараний рог «кульја», крест «саркай», кувшин «јыракы», сосуд для вина «тажуур», трубка самогонного аппарата «чорго» (Ямаева, 2004: 3). На рис. 2 мы видим лошадь с тамгой «саркай». Тавро передавалось по наследству от отца к сыну, по принципу минората. Известны случаи, когда тамгу полностью видоизменяли; причиной для этого могли служить постоянно преследующие владельца стад эпизоотии, либо, в районах наиболее подвергшихся русскому влиянию, потеря старого тавра. Возникновение родовой тамги определенного внешнего вида объясняется, как правило, стереотипной легендой, сводящейся к тому, что в хозяйствах данного сӧӧка постоянно рождались жеребята с похожим пятном на крупе «актанма» ${ }^{12}$.

Вместе с тамгами могут использовать метки на ушах. К примеру, алтайкижи Шебалинского района применяют надрезы различной формы на левом ухе животного как дополнение к тавру. Метки-надрезы могут быть также на правом и на обоих ушах животного. Вайнштейн С.И., изучавший клеймение скота на тувинском материале, отмечает, что метки-надрезы появились на Алтае в до-тюркскую эпоху. Кони, погребенные в Пазырыкском кургане, имели сложные надрезы на ушах (Вайнштейн, 1972: 80).

${ }^{12}$ Архив МАЭ РАН Ф.3, Оп.1, Д.14 Л.30. 

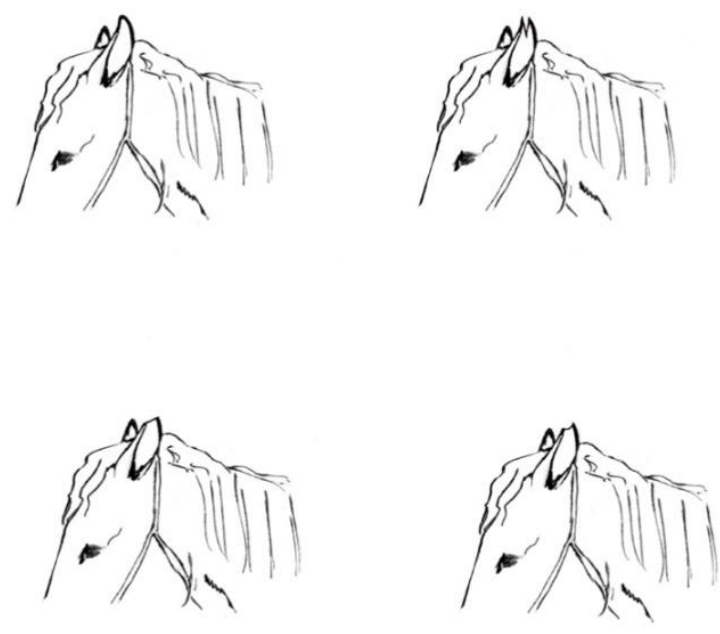

Рисунок 4. Варианты меток на ушах. Шебалинский район Республики Алтай; рис. Игнатьевой О.П. на базе эскизов из ПМА, 2006 г. ${ }^{13}$

В возрасте года (теленг.) или двух лет (алт.-к.) жеребятам впервые подрезают гриву и хвост. В дальнейшем подрезают только гриву ${ }^{14}$. Для процедуры применяют специальный нож «кылыш» (слово переводится как сабля, меч, кинжал).

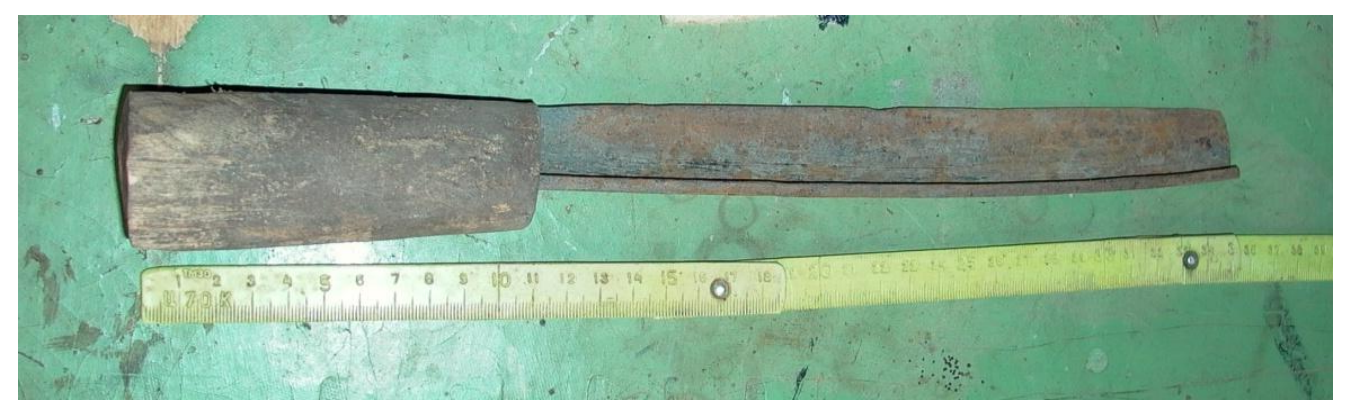

Рис. 5 Нож «кылыш» для подрезания гривы. Шебалинский район Республики Алтай. ПМА, 2006 г.

Применение подков в алтайской культуре зависит от локальных особенностей местности, в которой лошадь используют. Подковывают при работе на твёрдом, каменистом грунте или гололёде. Могут подковать только две передние ноги. Подковы часто используют русские, с шипами. Табунных лошадей не подковывают. Не кованых лошадей также используют под седло. Алтайцы подчёркивают, что животные, выросшие в табуне, обладают достаточной прочностью копыт, чтобы обходиться без ковки.

Продают лошадей алтайцы неохотно, в переговорах прибегают к услугам посредников, избегая прямой продажи, после совершения сделки у проданного животного срезают прядь из хвоста или гривы и хранят у себя год-два ${ }^{15}$. Исходя из цен, указанных в объявлениях о продаже сельскохозяйственных животных через интернет ресурс «Авито» в Республике Алтай в 2019 г.

\footnotetext{
${ }^{13}$ АРЭМ Ф.10 Оп.1 Д.204 Л.10.

${ }^{14}$ АРЭМ Ф.10 Оп.1 Д.204 Л.21.

${ }^{15}$ АРЭМ Ф.10 Оп.1 Д. 205 Л.15.
} 
стоимость коня колеблется в пределах 50-100 тысяч рублей, но если учесть, что большинство подобного рода сделок происходит, минуя фразу «свободной продажи», разброс цен представляется более значительным.

Под седло и алтай-кижи, и теленгиты заезжают животных между 3 и 4 годами. Сначала приучают к седлу, позже - к запряжке в телегу или сани. Процесс заездки обычно выглядит следующим образом: мужчины арканят животное, фриксируют у коновязи арканом «чалма», надевают недоуздок «нокто», узду, седлают, привязывают поводом недоуздка к коновязи и только потом садятся верхом, после чего отпускают повод недоуздка и аркан. Для того, чтобы окончательно укротить животное в среднем уходит около недели 10 дней, после чего, при необходимости, лошадь начинают обучать различным командам или тренировать для состязаний. Объезжают лошадей обычно умелые всадники небольшого веса, лёгкие ${ }^{16}$. Подходят к лошади и садятся на нее только с левой стороны. Как правило, под седло используются одни и те же животные, несколько из общего поголовья, хотя считается, что для работы можно подготовить любую лошадь и косячные жеребцы не являются исключением. Ездят, по словам информантов, на всех и на кобылах, и на меринах, и на жеребцах. Беременных кобыл не используют во избежание абортов. После выжеребки кобыла работает с жеребёнком ${ }^{17}$.

Клички лошадям алтайцы преимущественно дают в соответствии с окраской животного, или исходя из отличительных черт внешности или характера. Исключение делалось в случае, если жеребенок появлялся на свет одновременно с младенцем мужского пола. В этом случае коня называли тем же именем, что и ребенка. Традиционно для алтайцев вообще не была характерна устоявшаяся система личных имен, как для людей, так и для животных.

Алтайцы различают следующие основные масти лошадей:

\begin{tabular}{|c|c|c|c|}
\hline Масть & Оттенки & Описание & Алтайское название \\
\hline Рыжая & Светлая & $\begin{array}{l}\text { Одинаковая светло рыжая окраска } \\
\text { туловища и ног. Грива и хвост, а также } \\
\text { ноги ниже запястий и скакательных } \\
\text { суставов и конец моры - светлее. } \\
\text { Одинаковая темно рыжая окраска } \\
\text { корпуса и ног. }\end{array}$ & $\begin{array}{l}\text { Јеерен (рыжий) } \\
\text { Кызыл-јеерен } \\
\text { (красно-рыжий) }\end{array}$ \\
\hline Бурая & & $\begin{array}{l}\text { Окраска от грязно-рыжей, до каштановой. } \\
\text { Грива и хвост темнее туловища, часто с } \\
\text { примесью черных волос. }\end{array}$ & Кӱрен, \\
\hline Игреневая & $\begin{array}{l}\text { Темная } \\
\text { Светлая }\end{array}$ & $\begin{array}{l}\text { Шоколадная, часто в яблоках, хвост и } \\
\text { грива белые или дымчатые (белые } \\
\text { волосы с черными) } \\
\text { Окраска туловища близка к гнедой, но } \\
\text { хвост и грива белые или дымчатые. }\end{array}$ & Чалдар \\
\hline Вороная & & $\begin{array}{l}\text { Черная окраска туловища, ног, гривы и } \\
\text { хвоста. }\end{array}$ & $\begin{array}{l}\text { Кара (черный), кускун- } \\
\text { кара (черный как ворон) }\end{array}$ \\
\hline $\begin{array}{l}\text { Вороная в } \\
\text { загаре }\end{array}$ & & $\begin{array}{l}\text { Концы волос с порыжением, в связи с } \\
\text { чем, окраска туловища приобретает } \\
\text { грязно бурый оттенок. Голова, ноги и } \\
\text { хвост - черные. }\end{array}$ & \\
\hline Караковая & & $\begin{array}{l}\text { Черная окраска туловища, головы и ног, с } \\
\text { рыжими подпалинами на конце морды, } \\
\text { вокруг глаз, под брюхом и в пахах. }\end{array}$ & $\begin{array}{l}\text { Калтар (то же для } \\
\text { мухортой лошади) }\end{array}$ \\
\hline
\end{tabular}

\footnotetext{
${ }^{16}$ АРЭМ Ф.10 Оп.1 Д.204 Л.9, 39 об.

${ }^{17}$ АРЭМ Ф.10 Оп.1 Д.204 Л.17 об
} 


\begin{tabular}{|c|c|c|c|}
\hline Гнедая & Светлая & $\begin{array}{l}\text { Окраска туловища и головы красно- } \\
\text { коричневая разных оттенков. Грива и } \\
\text { хвост, и ноги ниже запястий и } \\
\text { скакательных суставов черные. } \\
\text { Окраска туловища и головы красно- } \\
\text { коричневая разных оттенков. Грива и } \\
\text { хвост черные, с примесью бурых волос. } \\
\text { На ногах ниже запястий и скакательных } \\
\text { суставов перемежается черная и } \\
\text { темнобурая окраска. На конце морды, } \\
\text { вокруг глаз и под брюхом окраска } \\
\text { светлее. }\end{array}$ & Кер, кара-кер \\
\hline Буланая & $\begin{array}{l}\text { Темная и } \\
\text { светлая }\end{array}$ & $\begin{array}{l}\text { Желтовато-золотистая или песчаная } \\
\text { различных оттенков (от близкой к светло- } \\
\text { гнедой до почти белой) окраска туловища } \\
\text { и головы. Грива, хвост и ноги ниже } \\
\text { запястий и скакательных суставов } \\
\text { черные. По хребту - ремень. }\end{array}$ & Кула \\
\hline Соловая & $\begin{array}{l}\text { Темная } \\
\text { Светлая }\end{array}$ & $\begin{array}{l}\text { Те же оттенки окраски, что и у буланой. } \\
\text { Голова и конечности одинаково } \\
\text { окрашены с туловищем. Грива и хвост } \\
\text { окрашены так же или светлее (могут быть } \\
\text { белыми). } \\
\text { Одноцветная } \\
\text { окраска. Лошади такой масти иногда } \\
\text { имеют сорочьи глаза. }\end{array}$ & $\begin{array}{l}\text { Ак-сары } \\
\text { желтая) }\end{array}$ \\
\hline Мышастая & $\begin{array}{l}\text { Темная } \\
\text { Светлая }\end{array}$ & $\begin{array}{l}\text { Окраска туловища темная, цвета золы. } \\
\text { Голова, грива, хвост и ноги ниже } \\
\text { запястий и скакательных суставов } \\
\text { черные. Вдоль хребта ремень. } \\
\text { Зольная окраска туловища и головы. На } \\
\text { конце морды и под брюхом посветление. } \\
\text { В гриве и хвосте вместе с черными - } \\
\text { темно-бурые волосы. Низы ног имеют } \\
\text { черно-бурый оттенок. Вдоль хребта } \\
\text { ремень. }\end{array}$ & Cyp \\
\hline Саврасая & $\begin{array}{l}\text { Гнедо- } \\
\text { саврасая } \\
\\
\text { Булано- } \\
\text { саврасая } \\
\text { Рыже- } \\
\text { саврасая }\end{array}$ & 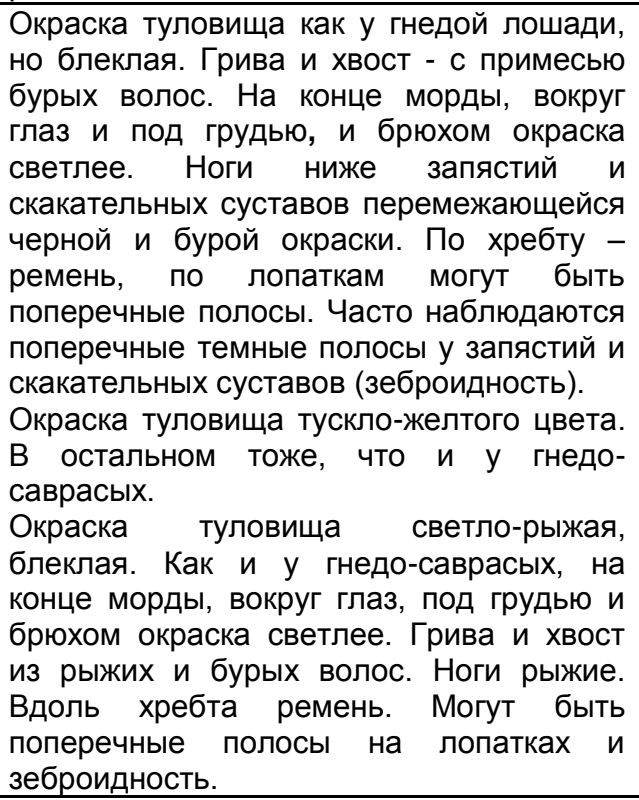 & Кула, сары \\
\hline Серая & $\begin{array}{l}\text { Светлая и } \\
\text { темная }\end{array}$ & $\begin{array}{l}\text { Окраска туловища из смеси черных и } \\
\text { белых волос. Постепенно с возрастом } \\
\text { она светлеет. Различают темно- и } \\
\text { светло-серую } \text { масть. Светло-серые }\end{array}$ & Боро, сур, кӧк-боро \\
\hline
\end{tabular}




\begin{tabular}{|c|c|c|c|}
\hline & $\begin{array}{l}\text { Рыже- } \\
\text { серая } \\
\text { Серая в } \\
\text { гречке }\end{array}$ & $\begin{array}{l}\text { лошади с возрастом становятся белыми. } \\
\text { Серые лошади могут быть в яблоках. } \\
\text { То же, что и в предыдущем случае, но в } \\
\text { смеси с белым и черным имеется и } \\
\text { рыжий волос. } \\
\text { У посветлевших взрослых лошадей } \\
\text { темные (черные и рыжие) волосы } \\
\text { образуют по корпусу точечные пятнышки. } \\
\text { Могут быть серые лошади в черной и } \\
\text { рыжей гречке. }\end{array}$ & \\
\hline Чалая & $\begin{array}{l}\text { Вороно- } \\
\text { чалая } \\
\text { Гнедо- } \\
\text { чалая }\end{array}$ & $\begin{array}{l}\text { Голова и ноги рыжие, на туловище по } \\
\text { основной рыжей масти равномерно } \\
\text { распределены белые волосы. } \\
\text { Голова, грива, хвост и ноги черные. По } \\
\text { туловищу равномерно распределены } \\
\text { черные и белые волосы. } \\
\text { Голова, грива, хвост и ноги черные. По } \\
\text { туловищу равномерно распределены } \\
\text { красно-коричневые и белые волосы. }\end{array}$ & Буурыл \\
\hline Чубарая & & $\begin{array}{l}\text { По белой окраске туловища разбросаны } \\
\text { темные пятна (черные или коричневые) } \\
\text { или по темному корпусу - белые пятна. }\end{array}$ & Чабдар, чоокыр, \\
\hline Пегая & $\begin{array}{l}\text { Рыже- } \\
\text { Гнедо- } \\
\text { Вороно- } \\
\text { и т.д. } \\
\end{array}$ & $\begin{array}{l}\text { По основной какой-нибудь масти (рыжей, } \\
\text { вороной, гнедой и т.д.) разбросаны } \\
\text { большие белые пятна. Ноги частично или } \\
\text { совсем белые. }\end{array}$ & Ала \\
\hline Сивая & & Серо-сизая; то же что серая & Боро \\
\hline Каурая & & $\begin{array}{l}\text { Светло-каштановая; то же что темно- } \\
\text { рыжая, бурая }\end{array}$ & Кӱрен \\
\hline
\end{tabular}

Информанты, рассматривая фротографии лошадей, зачастую расходятся во мнениях и называют разные термины, обозначающие масть животного, особенно если окраска может быть интерпретирована двояко, как в случае с бурыми и тёмно-рыжими лошадьми. Описывая лошадь, алтайцы обязательно обращают внимание на цвет и направление роста гривы, наличие отметин и особенностей конкретной особи. Например, Сары јалду калјан јееренкунан (С жёлтой гривой, и проточиной (лысиной) на морде рыжий трёхлеток).

Штатный забой лошадей производится осенью, выбирают животных не способных пережить зиму в условиях табуна. Коней убивают сильным ножевым ударом, направленным между первым шейным позвонком и основанием черепа либо, по словам Тадиной Н.А., в холку у седьмого шейного позвонка. Такой способ забоя называется «шукшулап» ${ }^{18}$. Для осуществления забоя животное загоняют в огороженное пространство, где его надо отловить и ударить ножом. Этот же способ применяется, если животное необходимо умертвить для свадебной или похоронной трапезы. Есть данные, что во время осеннего забоя лошадь могли умертвить, перерезав ей горло ${ }^{19}$. Культурный стереотип требует от каждого мужчины алтайца умения забить лошадь.

Конинина высоко ценится алтайцами и, из-за существенной дороговизны, всё больше переходит в категорию исключительно празднично-ритуальной пищи. Потапов Л.П. описывает следующие основные блюда из конского мяса: «чочух» из сумки конского сердца, наполненной мелко накрошенным мясом

\footnotetext{
${ }^{18}$ АРЭМ Ф.10 Оп.1 Д.204 Л.31 об.

${ }^{19}$ АРЭМ Ф.10, Оп.1 Д. 204 Л.20 об.
} 
вперемежку с салом и закопченной в дыму костра, отварное мясо и пожаренное на палочках на костре. С кониной могли приготовить и ячменную похлёбку «кӧчӧ» (Потапов, 1958: 56-57). Для улаганских теленгитов употребление в пищу мяса коня важная часть погребально-поминальных действий на похоронах мужчины. Лошадь забивают, варят мясо частями на протяжении трёх дней, и три дня приходят проводить усопшего. На третий день голову и копыта с путовыми суставами вывешивают на дерево к востоку от посёлка. Начинают приготовление блюд с требухи, и лишь затем готовят мясо $^{20}$. Локально зафиксированная в Улаганском районе традиция предписывает заколоть для тризны любимого верхового коня умершего. Традиция относительно новая, возникшая как компромисс между погребением с конём и требованиями, предъявляемыми советской администрацией. Для алтай-кижи блюда из конины являются непременным атрибутом свадебного угощения и их наличие на праздничном столе вопросом престижа молодой семьи, так как свадебный той традиционно весьма резонансное и длительно обсуждаемое событие ${ }^{21}$.

Как уже говорилось ранее, алтайские лошади круглогодично находятся на подножном корму, фактически в полудиком состоянии. Присмотр за табунами производится лишь самый незначительный. Традиционно возле юрт на привязи содержались дойные кобылицы и жеребята, а также верховые кони. Сейчас в посёлках остаются рабочие лошади, регулярно используемые для повседневных разъездов. Часть из них летом свободно пасётся в пределах сёл и деревень без надзора со спутанными ногами.

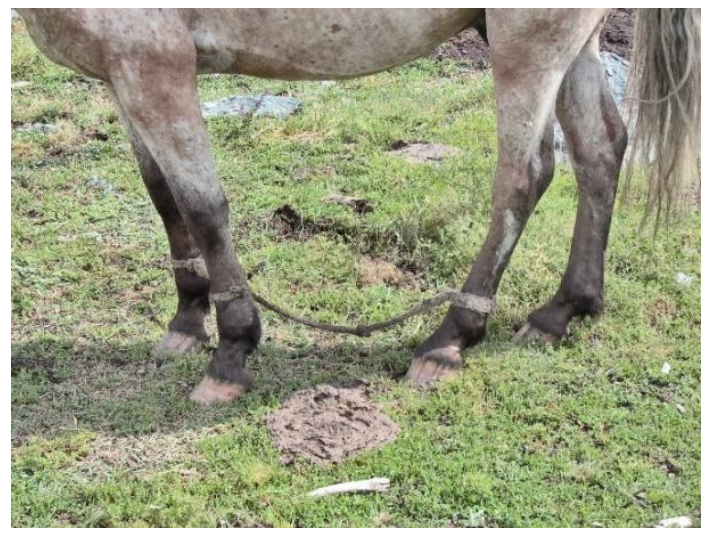

Рисунок 6. Путы типа «кижен». Улаганский район Республики Алтай. ПМА, 2006

Лошадей стреноживают, используя путы «тужак», представляющие собой веревку из конского волоса длиной около 75 см., с петлей на одном конце и узлом или застёжкой на другом, соединяющими две ноги лошади, либо путы «кижен» для трех ног, волосяные или из сыромятного ремня, с петлёй для задней ноги. Применение таких пут позволяет избежать потертостей на ногах у лошадей. В современном быту элементы амуниции из конского волоса всё чаще вытесняются сплетёнными в традиционной технике изделиями из пластиковых верёвок. Информанты старшего поколения отмечают негативное влияние синтетических пут на состояние ног животных.

\footnotetext{
${ }^{20}$ АРЭМ Ф.10 Оп.1 Д.204 Л.32

${ }^{21}$ АРЭМ Ф.10 Оп.1 Д.205 Л.3 об.
} 


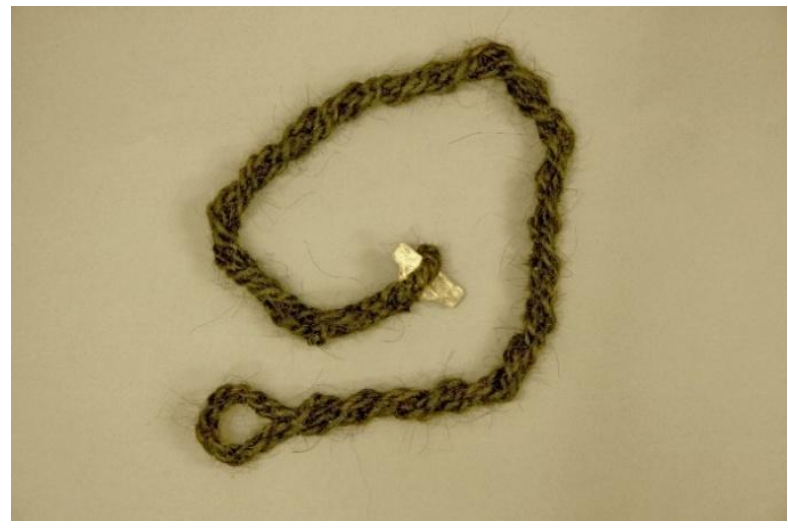

Рисунок 7. Путы типа «тужак». Шебалинский район Республики Алтай. ПМА, 2012

В случае, если во время остановки в пути лошадь было не к чему привязать, ее стреноживали поводом «чылбыр», закреплённым на недоуздке. Многие хозяева не снимают недоуздок с рабочей лошади до тех пор, пока не отпустят ее в табун.

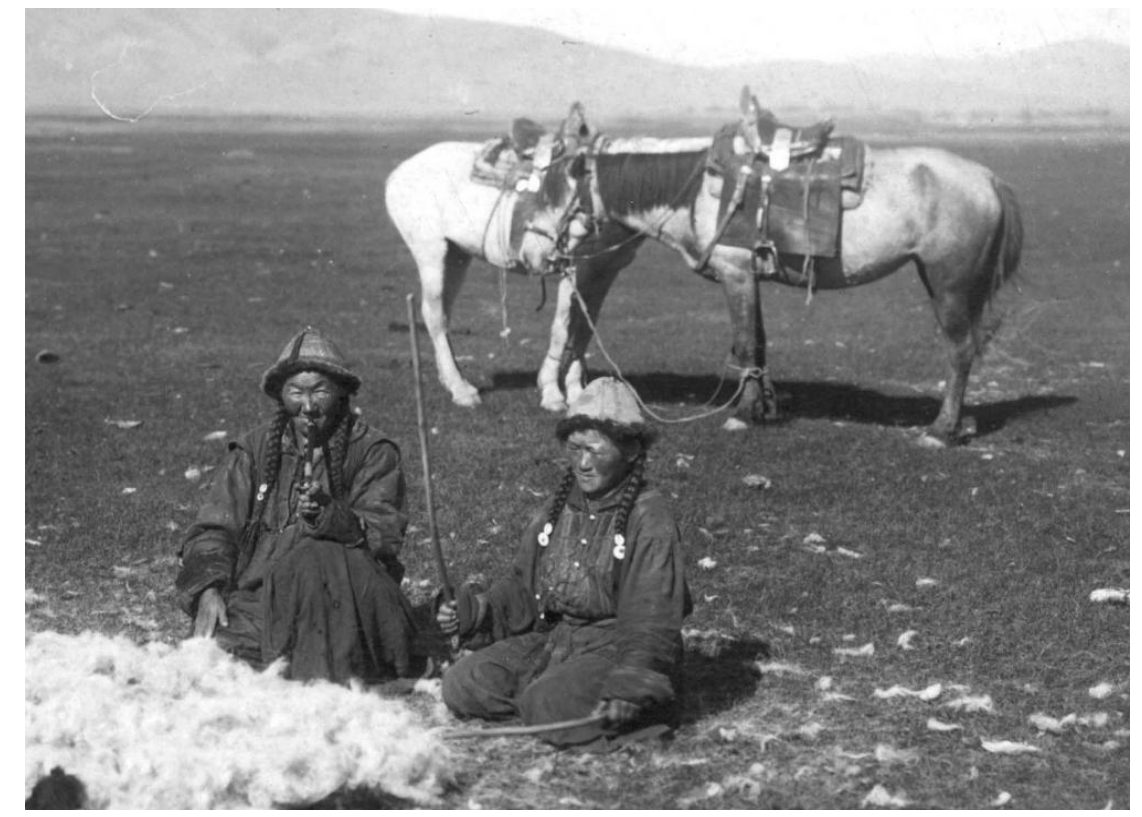

Рисунок 8. Лошади, спутанные поводом. Сайлюгемская степь, 1924. Теленгиты (РЭМ 4447-84 фрагмент.)

Верховая езда была самым распространенным способом перемещения алтайцев, и даже сейчас автотранспорт не может заменить лошадей в условиях пересеченного каменистого рельефа Республики. В этой связи неудивительно наличие в традиции собственного подвида южно-сибирского седла, характерного именно для данной культуры. Седло «ээр» имеет жесткий деревянный ленчик, собранный из пяти частей. Основу составляют парные боковины, к которым крепятся передняя и задняя дугообразные луки; зазор между верхними краями боковин седла закрывает кожаная, либо меховая продольная перемычка - живец. Возможна конструкция ленчика из четырёх частей, в которой полки седла просто смыкаются в верхней точке формируя 
свод. Форма лук, характерная для алтайских сёдел, напоминает седельные луки древнетюркского времени (Игнатьева, Ткаченко, 2006: 80). Деревянные части ленчика скрепляются между собой тонкими кожаными ремешками через специальные отверстия. Стременной ремень и подпруги «колон» также привязывают или пристёгивают к ленчику с помощью отверстий в полках. Для крепления подхвостника используют привязные ремешки, или ремешки с пряжками для пристёгивания. Поверх ленчика закрепляют седельную подушку «акта», которая может состоять просто из нескольких состеганных слоев войлока, но чаще всего обтягивается кожей или тканью. Полки седла в местах прилегания к спине животного подбиваются войлоком. Характерной чертой алтайских седел, является использование подхвостника при передвижении по гористой местности. Использование наперсного ремня возможно, но не обязательно. Нагрудники встречаются значительно реже, чем подхвостники. Существует несколько вариантов декорирования седельных лук, отображающих локальные традиции шорного дела. На старых сёдлах XIX-XX вв. чаще всего встречаются обтяжка тёмной (чёрной) кожей, окрашивание в красный цвет и отсутствие декора. Сёдла красного цвета обычно происходят из Улаганского района, сёдла в чёрной кожаной обтяжке, вероятно, тяготеют к бассейну р. Урсул (Игнатьева, Ткаченко: 80). В современном повседневном быту преобладают фрабричные «кавалерийские» верховые сёдла, с металлическими луками, простые деревянные сёдла алтайского типа встречаются изредка. Данная ситуация объясняется доступностью готовых кавалерийских сёдел. Мастера седельники в основном изготавливают специфические усиленные сёдла для национальных видов спортивных состязаний и сёдла алтайского типа для «парадных» выездов. Парадные сёдла, как правило, имеют богато декорированные тиснением кожаные элементы и орнаментированные металлические детали. Особенно популярны в современном седельном декоре мотивы скифо-сибирского звериного стиля.

Под седло в идеале подкладывается чепрак «кејим», состоящий из двух прямоугольных кусков плотной кожи, сшитых между собой продольно и, за счет шва, легко складывающийся пополам вдоль спины животного. Снизу, вдоль передней кромки кожаных полотнищ может проходить шов, при помощи которого к ним крепятся несколько слоев войлока. Полотнища войлока должны быть того же размера что и кожаный верх. На некоторых старинных чепраках, можно видеть полукруглые вырезы на месте задних углов полотнищ. Длина классического кожаного кејим довольно большая. Под чепрак подкладывают войлочный потник «токум». В повседневном обиходе в качестве чепрака и потника зачастую используются варианты сочетаний небольшого верхнего подседельного полотнища из кожи и разнообразных подкладок-потников из сочетания кусков войлока с байковыми фабричными одеялами, фррагментами хлопковых жаккардовых покрывал и тому подобных плотных бытовых тканей.

Стремена «ӱзени» делались преимущественно металлические, причем встречались как местной работы, так и покупные - русские и китайские. Стремена чаще всего арочные с круглой подножкой. Среди старых стремян часто встречаются экземпляры с серебряной орнаментальной насечкой. В собрании РЭМ числятся два деревянных стремени, поступившие с территории Республики Алтай из урочища Кумуртук ${ }^{22}$, одно значится теленгитским, другое - предположительно шорское, судя по всему стремена из дерева не были особо популярны.Стремена, по всей видимости, достаточно часто

${ }^{22}$ Российский этнографический музей (далее РЭМ) 4227-38; 6826-46. 
перестёгивались с одного седельного комплекта на другой. В этой связи сейчас можно встретить в обиходе седельный набор с современным фрабричным седлом и стременами конца XIX в. и наоборот, старый седельный набор с относительно новыми стременами.

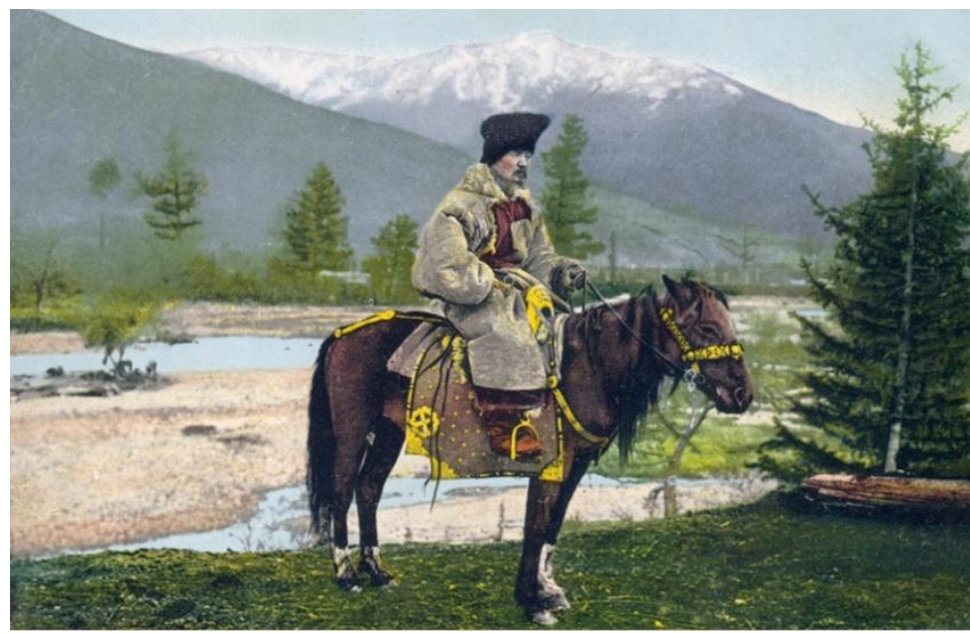

Рисунок 9. Седельный набор с классическим кејим.

(Тип алтайца. Открытка О-ва Грандберг, № 33, Стокгольм перв. четв. XX в).

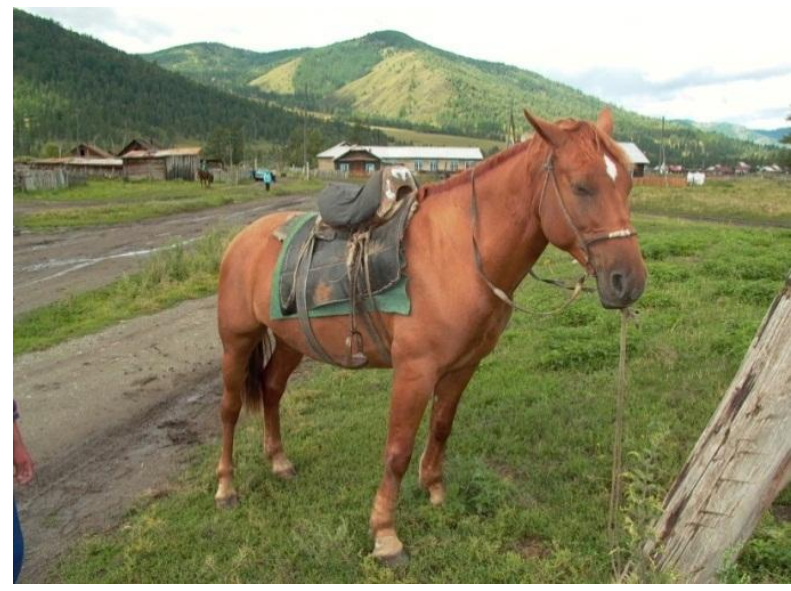

Рисунок 10. Современный седельный набор с упрощённым потником и стременами рубежа XIX-XX вв. Шебалинский район Республики Алтай. ПМА, 2006

Узда «ўйген» изготавливается либо из кожи, либо из конского волоса (пластиковой верёвки). Кожаные уздечки делятся на ременные и плетёные. Ременные дополнительно декорируются металлическими пластинами или заклёпками. Часть бытующих в настоящее время металлических пластин для декора ременной амуниции изготовлены на рубеже XIX и XX вВ., возможно ранее. Металлические бляхи используются и в декоре подхвостника «куйушкан», особенно в случае, если узда и подфея составляют единый набор. Для подхвостников вообще используют все те же материалы и приёмы декорирования, что и для уздечек, кроме того, известны также камусные подфеи. Плетёные кожаные уздечки в местах соединения ремней могут быть украшены фестонами из свёрнутой в декоративный рулон кожи. 


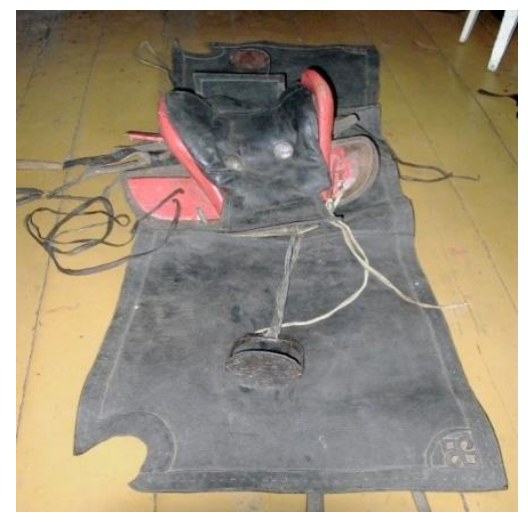

Рисунок 11. Седло и чепрак «кејим». Улаганский район Республики Алтай. ПМА, 2006 г.

Волосяные уздечки и недоуздки для украшения выплетали в два цвета: светлый и тёмный, либо сплетали нащёчные ремни зигзагами и фестонами. Составные части алтайской узды - два боковых ремня «экијаагы», оголовье «салдырга» и нахрапный ремень «кон жооры» (Тадина, 1995: 110). Удила трензельные, с небольшими кольцами с обеих сторон. Для алтайской узды характерно отсутствие налобного ремня. В качестве дополнительного декора могут служить кисти, бахрома или лоскуты материи, особенно если снаряжение принадлежит женщине. Встречаются уздечки, декорированные витками цветной изоляционной ленты.

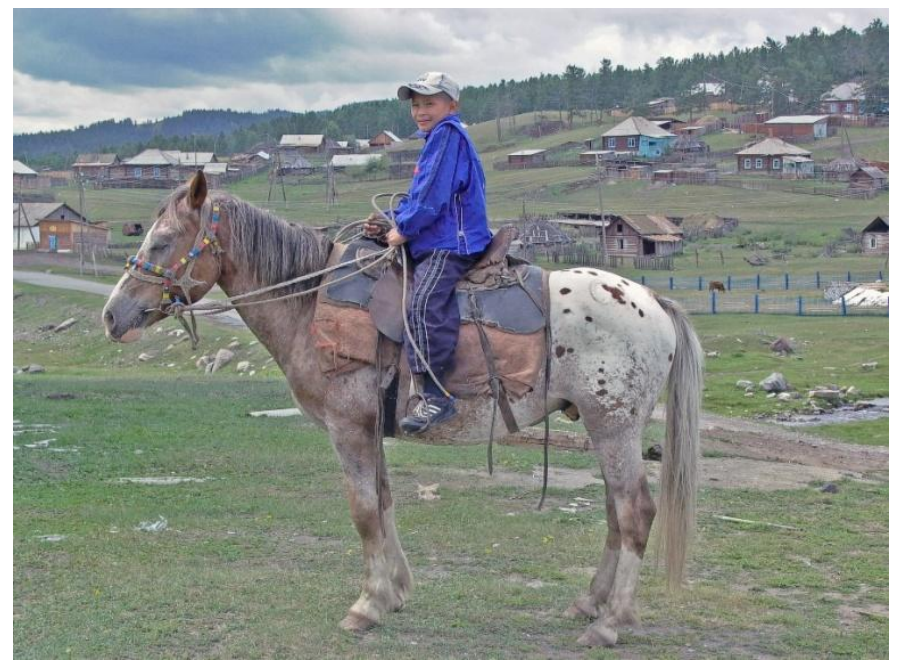

Рисунок 12. Узда из пластикового шпагата с декором из изоленты и типичный седельный набор. Улаганский район Республики Алтай. ПМА, 2006 г.

Под влиянием русских в обиход вошли уздечки с перекрестьем из ремней, соединяющим нахрапный и налобный ремни.

Различия между мужским и женским седельным набором достаточно трудноуловимы. В прошлом для парадного женского снаряжения были характерны фестончатые вышитые украшения подхвостников «талбак» (ЧоросГуркин, 2014: 218; МАЭ РАН И 122-33) и особая свадебная попона «бӱтелген», которой накрывалось женское седло. Такая попона практически всегда была синего цвета, и представляла собой прямоугольный кусок материи подшитой по краям; на переднем крае, в центре полотнища закладывалось несколько 
складок. По бокам, ближе к передней части делались прямоугольные разрезы, с нашитыми клапанами, предназначенные для продевания стремян ${ }^{23}$. Попона, по всей вероятности, была обязательна в торжественных случаях. Также в качестве отличий некоторые информанты-теленгиты называют чуть более скруглённую форму передней луки женского седла и декор из серебряных накладок на луках мужских сёдел (следует отметить, что относительно металлических накладок единого мнения нет, их приписывают и женским сёдлам $)^{24}$.

Данные о наличии в культуре специальных детских седел, сходных с казахскими «ашимай», отсутствуют. Детей приучают ездить верхом без седла или во взрослом седле, начиная с возраста 3-4 лет ${ }^{25}$. При дальних поездках дети могут ехать на лошади вместе с родителями или старшими сиблингами. В таком случае малышей сажают спереди «ӧнӧрип», а детей постарше - сзади, за седлом. Способ езды сзади называется «учкажып (учкашкан, учкаштырып)» (от учкаш, садиться вдвоём на одну лошадь).

Вьючные седла алтайцев конструировались по тому же принципу, что и верховые, но были значительно проще и легче, поскольку состояли из двух вытянутых прямоугольных дощечек скрепленных двумя дугами (Радлов, 1989: 158). В качестве основы для вьюков может с тем же успехом использоваться и верховое седло. Важным элементом конского снаряжения алтайцев являются перемётные сумы из кожи «арчымак» используемые на верховой лошади наряду с тороками для транспортировки имущества всадника. Старые арчымаки высоко ценятся алтайцами и не выходят из постоянного обихода. Купить такую перемётную суму у владельца практически невозможно.

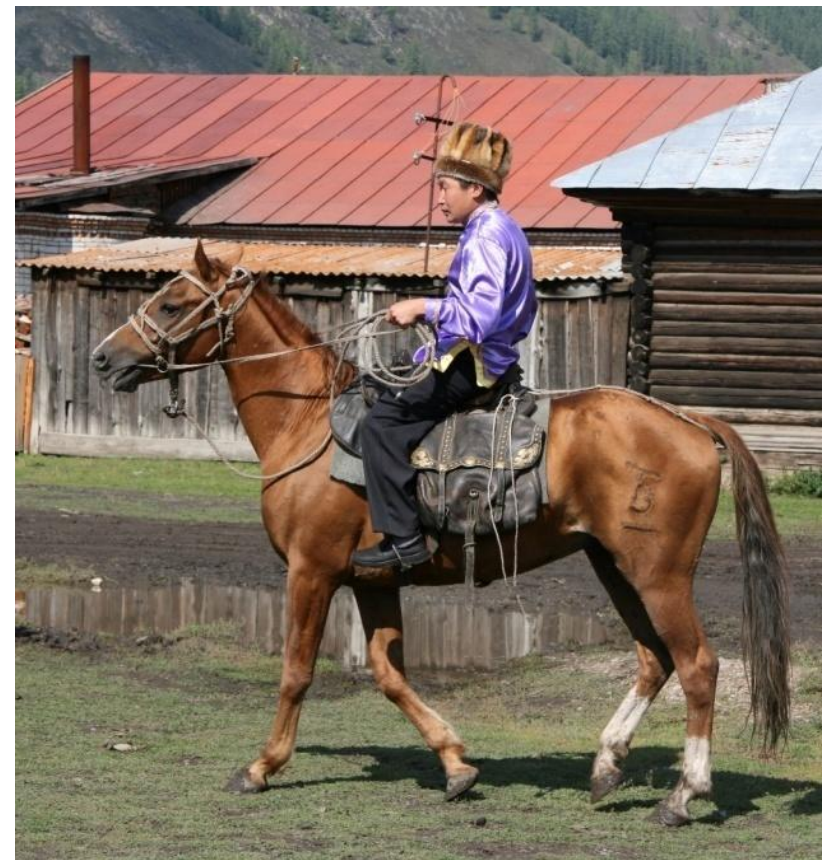

Рисунок 13. Старинные перемётные сумы на седле. Шебалинский район Республики Алтай. ПМА, 2008 г.

\footnotetext{
${ }^{23}$ Архив Музея антропологии и этнографии имени Петра Великого (Кунсткамера) АМАЭ РАН Ф.11 Оп.1 Д.130 Л.1.

${ }_{24}^{24}$ АРЭМ Ф.10 Оп.1 д.204 л.Л. 32, 42,42 об.

${ }^{25}$ АРЭМ Ф.10 Оп.1 Д.204 Л.33.
} 
Важной принадлежностью всадника является плеть. Классическими для теленгитов можно считать плети с рукоятками из краснотала (род ивняка) длиной в три хвата руки, с кожаным спуском, сердечником из сыромятного кожаного ремня, надсечённым в трёх местах, и оплёткой в восемь ремней с непременной сменой плетения у кончика. Такие плети помимо практического своего назначения наделяются магическими свойствами. Считается, что такая плеть поможет путнику преодолеть так называемые «тургактујер» - «трудные места» на дороге, в пределах которых не идёт конь, глохнет техника и чудится странное ${ }^{26}$. Плети, используемые алтай-кижи, менее тяготеют к единой форме.

Для перевозки крупных грузов могут использоваться телеги. Двуколка является типом транспорта, дошедшим до нашего времени практически без изменений, на фотографии, сделанной в Шебалинском аймаке в 1929 г., из собрания МАЭ РАН, можно видеть двуколку с оглобельно-дуговой хомутовой одноконной запряжкой в сочетании с верховым седлом, в котором расположился всадник, правящий лошадью ${ }^{27}$. Такую же конструкцию мы с Ткаченко И.Д. зафриксировали в Шебалинском районе в 2006 г. с единственным отличием: вместо деревянных тележных колёс современные двуколки ставят на колёса от легковых автомобилей.

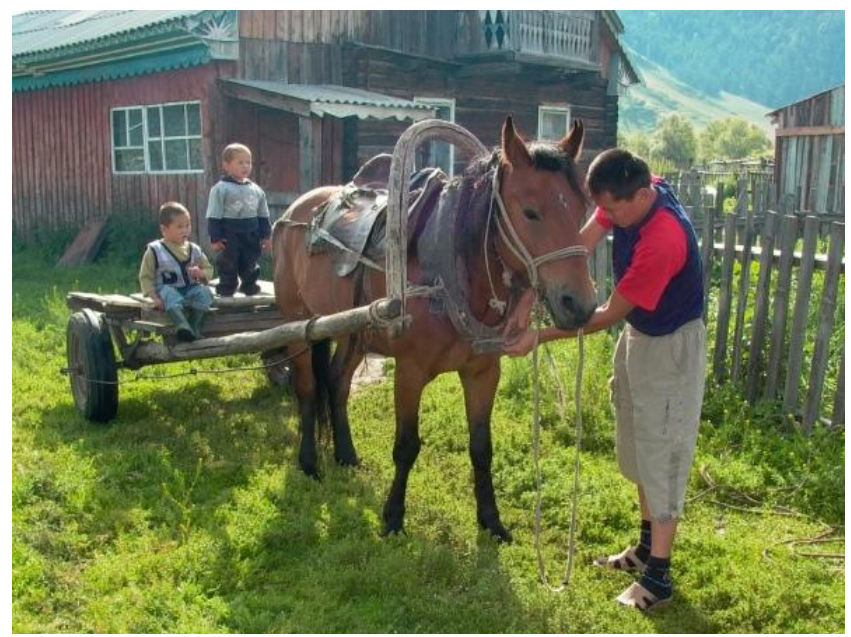

Рисунок 14. Двуколка. Шебалинский район Республики Алтай. ПМА, 2006 г.

В настоящее время важную роль для культуры алтайцев вновь обретают конные спортивные состязания. В Республике проводятся гладкие скачки и рысистые бега с участием лошадей культурных верховых и рысистых пород и их гибридов, выездка и конкур популярны значительно меньше. Наибольший же интерес представляют соревнования с участием лошадей местного табунного разведения, восходящие к национальным видам спорта. Таковыми являются скачки по пересечённой местности на дистанцию 12 км, скачки иноходью, козлодрание «кӧкбӧрӱ» и «эмдикатӱредиш» - укрощение дикой лошади на время. Последнее состязание проходит следующим образом: команда из трёх человек отлавливает в табуне диких лошадей животное той масти, которую определил жребий, выгоняет ее на аркане к коновязному

\footnotetext{
${ }^{26}$ АРЭМ Ф.10 Оп.1 Д.204 Л.37.

27 МАЭ РАН 4124-3. Данилин А. Г., Каруновская Л. Э. На двуколке на покос. Фотоотпечаток. Алтайцы. Алтай, Шебалинский р-он (Ойротская автономная область, Шебалинский аймак), 1929.
} 
столбу либо загоняет в раскол, взнуздывает и седлает специально усиленным седлом кавалерийского типа с двумя подпругами и обязательной подфеей, после чего наездник должен продержаться в седле одну минуту с поднятой вверх рукой (ПМА, 2012; Пронина, 2017). Призовой фонд состязаний может быть достаточно внушительным, однако далеко не всегда выигрыш перекрывает затраты, связанные с подготовкой лошади к состязаниям и приобретением амуниции. Вообще во всём, что связано с лошадьми понятие практичности отходит для алтайцев на задний план, если только не идёт речь о жизни и безопасности животных.

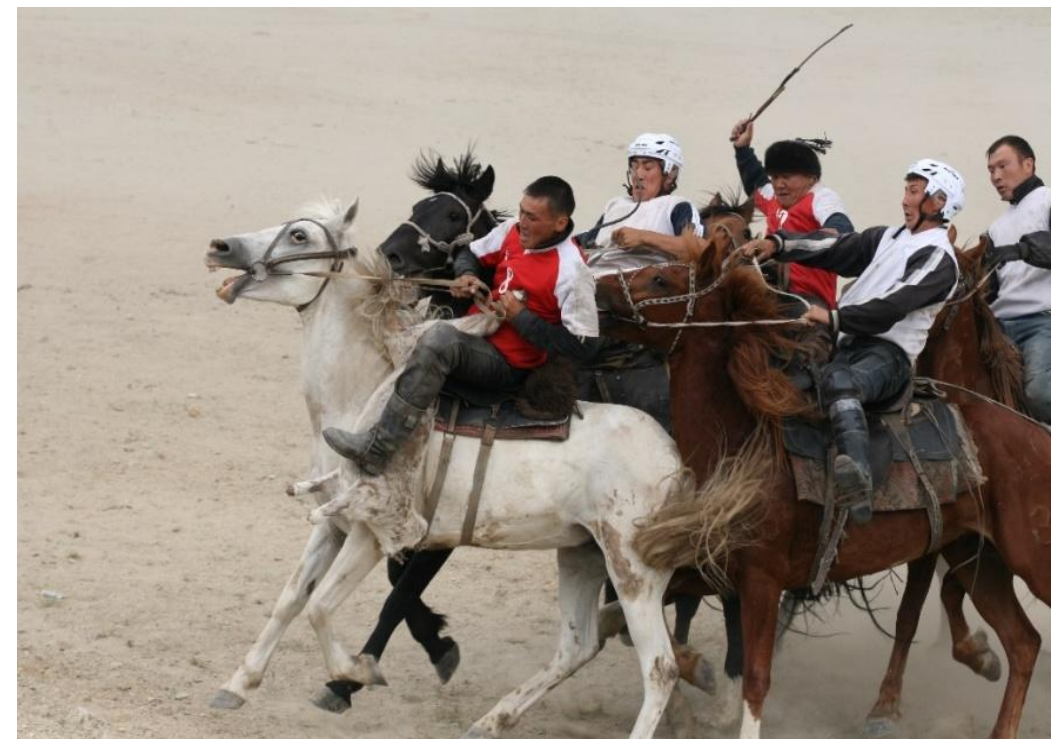

Рисунок 15. Кӧкбӧрӱ. Эл Ойын. ПМА, 2012 г.

Заключение. Особое положение коня в воззрениях алтайцев требует отдельной большой статьи. Отметим, что коневодство является своего рода стержнем мужского мира алтайцев. Лошадь для алтайца и «эрјине» сокровище и «койлогоат» - конь, которого похоронят вместе с хозяином. Количество лошадей на душу населения, содержащееся в алтайских хозяйствах, можно назвать избыточным, продуктивная ценность лошадей минимальна, но, с точки зрения носителей культуры, их наличие в быту и сохранение навыков обращения с ними необходимое условие сохранения этнической идентичности и витальности народа. Представления о мужчинеалтайце как о «эмдикчи» укротителе диких коней находит современные фрормы художественного воплощения. В 2017 г. при поддержке Министерства культуры вышел фрильм Михаила Куланакова «Трико», в котором через мотив первой в жизни мальчика заездки дикого коня передана идея ответственности мужчины перед семьёй и родом.

Несмотря на то, что в повседневном быту алтайцы зачастую используют метисированных лошадей самого разного происхождения, они с гордостью и любовью отзываются о национальной породе, сохраняется преемственность среди мастеров-шорников, немного найдётся алтайцев совершенно не умеющих держаться в седле и обращаться с лошадьми. Приспосабливаемость к новым условиям и материалам, попытки экспериментов в племенном разведении - всё это говорит о том, что мы имеем дело с живой и непрерывной коневодческой традицией. 


\section{Әдебиеттертізімі / Список литературы}

1. Алтайские, 1997 - Алтайские героические сказания: Очи-Бала. Кан-Алтын. Новосибирск: Наука, 1997. - 668 с.

2. Алтайско-русский, 2018 - Алтайско-русский словарь. Редколлегия: канд. ффилол. наук А.Э. Чумакаев(отв. ред.), канд. ист. наук Н.В. Екеев, канд. филол. наук А.Н. Майзина, К.К. Пиянтинова, Н.Н. Тыдыкова, канд. фрилол. наук Е.В. Тюнтешева; БНУ РА «НИИ алтаистики им. С.С. Суразакова». ГорноАлтайск, 2018. - 936 с.

3. Бороздин, 191? - Бороздин В.Г. Альбом разных русских и иностранных пород лошадей. СПБ. Издание К Добролюбова. Типо-лит. В.Кене и Ко, [191?] - 211 с.

4. Ванштейн, 1972 - Ванштейн С.И. Историческая этнография тувинцев. М.:Наука, 1972. -314 с. 5. Жилинский, 1948 - Жилинский А.А. Конские породы Сибири. Новосибирск.: Новосибгиз, 1948. (3-я тип.Трансжелдориздата). - 168 с.

6. Игнатьева, 2012 - Игнатьева О.П. Конь как часть идеального мира алтайцев//Основные тенденции развития алтаистики в изменяющихся мировоззренческих условиях: Материалы межд.науч.-практ.конф., посв. 1150 летию рос.гос-ти, 90-летию Ойрот.авт.обл., 60-летию Науч.исслед. ин-та алтаистики им. С.С. Суразакова (Горно-Алтайск, 26-30 июня 2012 г.). ГорноАлтайск, 2012. Ч. 1.

7. Игнатьева, 2006 - Игнатьева О.П., Ткаченко И.Д. Из истории развития конского верхового седла на Алтае.// Алтай - Россия: через века в будущее. - Горно-Алтайск, 2006. Т. 1.

8. Лобанова, Трушников, 2005 - Лобанова Т.В., Трушников В.А. Алтайская лошадь и этапы ее преобразования//Вестник Алт.ГАУ. 2005. №1(17).

9. Потапов, 1953 - Потапов Л.П. Пища алтайцев (этнографический очерк) // Сб. МАЭ. М-Л.: Наука, 1953. T. XIV.

10. Пронина, 2017 - Пронина Т. Конные забавы. Алтай. Скачки и объездка мустангов. ИП «Рябинина Ю.Б.» по зак. ЗАО «Первый ТВЧ», 2017.

11. Радлов, 1989 - Радлов В.В. Из Сибири: страницы дневника. М.: Наука, Главная редакция восточной литературы, 1989. - 749 с.

12. Русско-Алтайский, 1963 - Русско-Алтайский словарь. Под ред. Н.А. Баскакова. М., «Советская энциклопедия», 1963. - 875 с.

13. Тадина, 1995 - Тадина Н.А. Алтайская свадебная обрядность (XIX-XX вв.). Горно-Алтайск: Горно-Алт. респ. кн. изд-во, 1995. - 214,[1] с.

14. Тюхтенева, 2017 - Тюхтенева С.П. Одна чёрточка - одна сотня: к вопросу о способах подсчёта скота у тюрко-монгольских народов. // Вестник Калмыцкого института гуманитарных исследований РАН. 2017. №5(33)

15. Чаптынов, 1986 - Чаптынов В. В горном Алтае. // Коневодство и конный спорт. 1986. №6.

16. Чорос Гуркин, 2014 - Чорос Гуркин Г.И. Украшение подхвостника женского седла. Рисунок. 1930. // Этнографические рисунки Г.И. Чорос-Гуркина. Альбом. Горно-Алтайск: Ак Чечек, 2014. - 252 c.

17. Ямаева, 2004 Ямаева Е.Е. Родовые тамги алтайских тюрок (XIX-XX вв.). Горно-Алтайск, 2004. -56 c.

\section{References}

Altajskie, 1997 - Altajskie geroicheskie skazaniya: Ochi-Bala. Kan-Altyn. Novosibirsk: Nauka, 1997. 668 s. [In Rus.]

Altajsko-russkij, 2018 - Altajsko-russkij slovar'. Redkollegiya: kand. filol. nauk A.E. CHumakaev (otv. red.), kand. ist. nauk N.V. Ekeev, kand. filol. nauk A.N. Majzina, K.K. Piyantinova, N.N. Tydykova, kand. filol. nauk E.V. Tyuntesheva; BNU RA «NII altaistiki im. S. S. Surazakova». GornoAltajsk, 2018. - 936 s. [In Rus.]

Borozdin, 191? - Borozdin V.G. Al'bom raznyh russkih i inostrannyh porod loshadej. SPB. Izdanie K Dobrolyubova. Tipo-lit. V.Kene i Ko, [191?]. - 211 s. [In Rus.]

Vanshtejn, 1972 - Vanshtejn S.I. Istoricheskaya etnografiya tuvincev. M.:Nauka, 1972. - 314 s. [In Rus.]

ZHilinskij, 1948 - Zhilinskij A.A. Konskie porody Sibiri. Novosibirsk.: Novosibgiz, 1948. (3-ya tip. Transzheldorizdata). - $168 \mathrm{~s}$.[In Rus.]

Ignat'eva, 2012 - Ignat'eva O.P. Kon' kak chast' ideal'nogo mira altajcev//Osnovnye tendencii razvitiya altaistiki $v$ izmenyayushchihsya mirovozzrencheskih usloviyah: Materialy mezhd. nauch.-prakt.konf., posv. 1150 letiyu ros.gos-ti, 90-letiyu Ojrot.avt.obl., 60-letiyu Nauch.-issled. in-ta altaistiki im. S.S. Surazakova (Gorno-Altajsk, 26-30 iyunya 2012 g.). Gorno-Altajsk, 2012. CH. 1. [In Rus.]

Ignat'eva, 2006 - Ignat'eva O.P., Tkachenko I.D. Iz istorii razvitiya konskogo verhovogo sedla na Altae.// Altaj - Rossiya: cherez veka v budushchee. - Gorno-Altajsk, 2006. T. 1. [In Rus.] 
Lobanova, Trushnikov, 2005 - Lobanova T.V., Trushnikov V.A. Altajskaya loshad' i etapy ee preobrazovaniya//Vestnik Alt.GAU. 2005. №1(17). In Rus.]

Potapov, 1953 - Potapov L.P. Pishcha altajcev (etnograficheskij ocherk) // Sb. MAE. M-L.: Nauka, 1953. T. XIV. [In Rus.]

Pronina, 2017 - Pronina T. Konnye zabavy. Altaj. Skachki i ob"ezdka mustangov. IP «Ryabinina YU.B.» po zak. ZAO «Pervyj TVCH», 2017. [In Rus.]

Radlov, 1989 - Radlov V.V. Iz Sibiri: stranicy dnevnika. M.: Nauka, Glavnaya redakciya vostochnoj literatury, 1989. - 749 s. [In Rus.]

Russko-Altajskij, 1963 - Russko-Altajskij slovar'. Pod red. N.A. Baskakova. M., «Sovetskaya enciklopediya», 1963. - 875 s. [In Rus.]

Tadina, 1995 - Tadina N.A. Altajskaya svadebnaya obryadnost' (XIX-XX vv.). Gorno-Altajsk: Gorno-Alt. resp. kn. izd-vo, 1995. - 214,[1] s. [In Rus.]

Tyuhteneva, 2017 - Tyuhteneva S.P. Odna chyortochka - odna sotnya: k voprosu o sposobah podschyota skota u tyurko-mongol'skih narodov. // Vestnik Kalmyckogo instituta gumanitarnyh issledovanij RAN. 2017. №5(33). [In Rus.]

CHaptynov, 1986 - Chaptynov V. V gornom Altae. // Konevodstvo i konnyj sport. 1986. №6. [In Rus.]

Choros-Gurkin, 2014 - Choros-Gurkin G.I. Ukrashenie podhvostnika zhenskogo sedla. Risunok. 1930. // Etnograficheskie risunki G.I. CHoros-Gurkina. Al'bom. Gorno-Altajsk: Ak CHechek, 2014. - 252 s. [In Rus.]

YAmaeva, 2004 YAmaeva E.E. Rodovye tamgi altajskih tyurok (XIX-XX vv.). Gorno-Altajsk, 2004. - 56 s. [In Rus.]. 